OPTIMUM. STUDIA EKONOMICZNE NR 1 (85) 2017

\author{
dr Lidia KLOS \\ Wydział Nauk Ekonomicznych i Zarządzania, Uniwersytet Szczeciński \\ e-mail: lidia.klos@wneiz.pl
}

DOI: 10.15290/ose.2017.01.85.10

\title{
UWARUNKOWANIA EKOMIGRACJI W POLSCE
}

\section{Streszczenie}

Migracja, czyli przemieszczanie się mas ludzi z jednego miejsca do drugiego, jest typowym zjawiskiem, które występowało, występuje i będzie występować w każdym kraju. Wyróżnia się migracje zewnętrzne - z jednego kraju do drugiego i migracje wewnętrzne, które oznaczaja przemieszczanie się ludności w obrębie jednego kraju. Ostatnio pojawił się nowy rodzaj migracji wewnętrznej, zwany ekomigracją lub ekouchodźctwem, spowodowany względami środowiskowymi. Pogarszające się warunki środowiska naturalnego w dobie wzrastającej świadomości ekologicznej stanowią istotną motywację do zmiany warunków życia na lepsze.

Celem artykułu jest przybliżenie zjawiska ekomigracji, jakie w ostatnim czasie pojawiło się również w Polsce. W związku z tym, jako metodę badań wykorzystano studium indywidualnego przypadku na przykładzie miasta Kraków.

Słowa kluczowe: migracje, zanieczyszczenia, ekomigracje, ekouchodźcy

\section{DETERMINANTS OF ECO-MIGRATION IN POLAND}

\section{Summary}

Migration, which is a movement of masses of people from one place to another, is a phenomenon which has occurred throughout the world since times immemorial, and is likely to continue. Reasons for migrations vary, but the common denominator is a desire for better living conditions. We can distinguish external migration, from one country to another, and internal migration, which means population movements within a country. Recently a new kind of internal migrants have appeared: "eco-migrants" or "eco-refugees", motivated by environmental concerns. Citizens have started to abandon crowded, inconvenient and polluted metropolitan areas for the comfort of the countryside, where they can breathe uncontaminated air, and enjoy peace and silence.

The aim of the paper is to examine the phenomenon of "eco-migration", which has also been observed in Poland in recent times. For this purpose, the case study of Cracow was used as a method of research.

Key words: migrations, pollutions, eco-migrations, eco-refugees

JEL: Q52,Q54 


\section{Wstęp}

Od zamierzchłych czasów ludzie przemieszczali się z jednego miejsca w inne. Początkowo przebywali nieodkryte lądy, zasiedlali nowe kontynenty, by w erze industralizacji „poruszać” się pomiędzy miastami i wsiami. Przez setki lat obserwowano, jak ludność wiejska wyrusza do miast. Natomiast w ostatnim czasie zauważa się nową tendencję związana z migracją ludności z miasta na wieś, której przyczyną są względy środowiskowe. Ludzie uciekaja z miasta na wieś w poszukiwaniu spokoju, którego nie zaznają w wielotysięcznej aglomeracji. Uciekają od smogu, hałasu i stresu wywołanego tempem życia w mieście. Opuszczają mieszkania w wielkich blokowiskach na rzecz ciszy i spokoju, jakie daje wieś, gdzie mogą odpocząć od hałasu, pooddychać świeżym powietrzem, rozkoszować się słońcem, wszechobecną zielenia. Pogarszające się warunki środowiska naturalnego w dobie wzrastającej świadomości ekologicznej stanowią istotny impuls do zmiany warunków życia na lepsze.

Celem artykułu jest przybliżenie zjawiska ekomigracji, jakie w ostatnim czasie pojawiło się również w Polsce. W związku z tym, wykorzystano studium indywidualnego przypadku jako metodę badań.

\section{Migracje jako przedmiot refleksji naukowej}

Migracja (lac. migratio - przesiedlenie lub synonimicznie - wędrówka, ruchliwość przestrzenna) to względnie trwała zmiana miejsca pobytu jednostek i grup w ramach określonej przestrzeni [por.: Maryański, 1984, s. 7; Dobosiewicz, Olszewski, 1982, s. 91; Holzer, 1994, s. 282; Latuch, 1985, s. 307; Rosset, 1975, s. 512].

Przyczyny tego zjawiska są różne, ale najważniejsze z nich to poszukiwanie lepszych warunków do życia. Jednocześnie można wymienić migracje polityczne i religijne. Niezależnie od przyczyn, które dany ruch migracyjny wywołały, rodzi on podobne problemy - prawne, ekonomiczne, humanitarne, społeczne, polityczne, kulturowe, psychologiczne - zarówno dla krajów przyjmujących, jak i dla instytucji międzynarodowych (międzyrządowych i pozarządowych). Migracje to nie tylko proste występowanie ruchów wędrówkowych podejmowanych z niezależnych powodów przez miliony jednostek ludzkich. Sa to także procesy powodowane i jednocześnie warunkowane przez: rytm życia gospodarczego poszczególnych państw i ogólniejsze trendy ekonomiczne, stan stosunków międzynarodowych, ewolucję koncepcji praw człowieka oraz dysproporcje między zakresem spełnienia pakietu praw politycznych z jednej strony, a pakietu praw ekonomicznych $z$ drugiej [Zolberg, 1989]. To te siły sprawcze determinują w równej mierze czynniki wypychające (wyzwalające ciśnienie migracyjne), jak i przyciagające, a więc wskazujące możliwe kierunki jego rozładowania. Dlatego procesy migracyjne od lat znajdują się w kręgu zainteresowania różnych dyscyplin naukowych, takich jak m.in.: statystyka, geografia ekonomiczna, demografia i socjologia, a ostatnio również i ekonomia.

Choć badania nad migracjami w każdej z wymienionych dyscyplin maja ponad stuletnią tradycję, to większość sformułowanych twierdzeń teoretycznych nie może być 
interpretowana jako generalizująca, lecz jako konstatacje zależne od odniesień czasowych i przestrzennych. Wynika to nie tyle z ułomności refleksji teoretycznej, ale z natury migracji. Mimo że występują i występowały one zawsze, to konkretne procesy migracyjne maja z reguły własne konfiguracje przyczyn, formy przebiegu, odmienną ważność. Jak zauważył Aristide R. Zolberg [1989], wiedza o migracjach w coraz wyższym stopniu staje się konkretnohistoryczna, traktuje procesy wędrówkowe raczej w kategoriach strukturalnych niż jednostkowych oraz uwzględnia wyraźniej niż kiedyś ich kontekst globalny, w tym międzynarodowe procesy polityczne i ekonomiczne.

Współcześnie w stosunku do migracji są formułowane następujące twierdzenia:

- międzynarodowe migracje drugiej połowy XX wieku przede wszystkim wiąża się z konfrontacją Południa (demograficznie prężnego, ale biednego) z Północa (o malejącym przyroście naturalnym, lecz dostatnia);

- migracje te generują dysproporcje między poziomem osiagniętych już swobód politycznych (prawem wyboru sposobu życia, zachowania lub zmiany tożsamości kulturowej, opuszczenia kraju zamieszkania oraz powrotu do niego) a tempem znoszenia nierówności rozwoju cywilizacyjnego (kontynentów, krajów, regionów, wsi i miast);

- $\quad$ istnieje silna korelacja między stopniem modernizacji określonego kraju a charakterem ruchów migracyjnych. Kraje znajdujące się we wczesnych stadiach procesów modernizacyjnych wysyłają emigrantów. Zaawansowane fazy modernizacji rodzą natomiast zapotrzebowanie na imigrantów i determinują podstawowe charakterystyki strumienia imigracyjnego (m.in.: jego natężenie, cechy demograficzne i społeczno-zawodowe [Appleyard, 1991, s. 6];

- $\quad$ w tradycyjnych krajach imigracyjnych spada zapotrzebowanie na niewykwalifikowaną i nisko wykwalifikowaną siłę roboczą a jednocześnie rośnie popyt na wykwalifikowane zasoby ludzkie. Migracje opisywane metaforycznie jako mymiana mózgón - drenaż mózgón zaczynają tworzyć stos pacierzowy europejskiego systemu migracyjnego [Salt, 1989, s. 450-45]. Współcześnie europejscy profesjonaliści i kontraktowi robotnicy wykwalifikowani coraz częściej kierują się nie do tradycyjnych krajów imigracyjnych, lecz do najszybciej rozwijających się regionów świata [Ottolenghi, 1994, s. 12];

- ma miejsce bezpośrednia zależność między typami migracji (uchodźcami i azylantami w szczególności) a typami konfliktów (społecznych, politycznych, etnicznych, ekonomicznych), które je spowodowały [Zolberg, 1989, s. 11-13];

- intensywnych migracji wewnętrznych nie da się oddzielić od międzynarodowych, a jednych i drugich od nierówności regionalnych i bezpieczeństwa globalnego [Widgren, 1990, s. 25].

Migracje można sklasyfikować według poniższych kryteriów.

1. Zakres wolności decyzji migracyjnych. Na tej podstawie wyróżnia się migracje dobrowolne (gdy migranci decydują się opuścić określone terytorium bez presji wywieranej przez instytucje polityczne; $\mathrm{w}$ tym rozumieniu emigracja „za chlebem” jest dobrowolna) i przymusowe (gdy o przemieszczaniu decydują władze, taki charakter maja np.: wydalenia lub wypędzenia, wysiedlenia i przesiedlenia, deportacje i ewakuacje). 
2. Sposób przygotowania do migracji. Kryterium to pozwala wyodrębnić migracje spontaniczne i planowane, podjęte po odpowiednim, często długotrwałym, przygotowaniu.

3. Przyczyny migracji. Cecha ta umożliwia m.in.: odróżnienie migracji zarobkowych od politycznych (powodowanych sprzeciwem wobec systemu politycznego, chęcią ucieczki przed represjami i innymi motywami), innowacyjnych (inspirowanych ideologicznymi lub religijnymi utopiami) od konserwatywnych, motywowanych dążeniem do odcięcia się od niepożądanego kierunku zmian i nadzieją na odtworzenie starego stylu życia w nowym miejscu osiedlenia. Ponadto, podobny sposób, tj. według przyczyn, wyróżnia się migracje emerytalne oraz migracje związane z łączeniem rodzin czy zawarciem związku małżeńskiego.

4. Status prawny migranta i zakres jego uprawnień w kraju imigracyjnym (np.: do wykonywania pracy zarobkowej, uczestnictwa w życiu politycznym), w wyniku którego dzieli się migrantów na legalnych i nielegalnych.

5. Liczba osób wspólnie migrujących (migracje indywidualne, w grupach rodzinnych, migracje podporządkowane).

6. Czas trwania migracji pozwala na analityczne wyodrębnienie emigracji, a mianowicie stałych (tj. osiedlania się na stałe poza terytorium kraju pochodzenia), okresowych (w tym sezonowych, związanych z praca w: rolnictwie, budownictwie, usługach) i codziennych (określanych także mianem wahadlowych).

7. Terytorium docelowe, to kryterium porządkuje ruchy migracyjne na wewnętrzne (tj. w ramach danego terytorium państwa; w tym międzyregionalne i wewnątrzregionalne) i zewnętrzne (rozpoczynające się po przekroczeniu granicy państwa, tj.: międzynarodowe, w ramach regionalnej grupy państw, kontynentalne, międzykontynentalne).

8. Charakter jednostki osiedleńczej pozwala wyróżnić migracje ze wsi do miast (i odwrotnie) oraz pomiędzy wsiami, a także pomiędzy miastami [Encyklopedia sojologii, 1999, s. 247].

Powyższe typologie, choć tak rozbudowane, nie są wyczerpujące. Zwłaszcza w odniesieniu do migracji międzynarodowych, które jeszcze dzieli się na: migracje stałe, migracje okresowe robotników kontraktowych, migracje czasowo zatrudnionych za granicą profesjonalistów i wykwalifikowanych robotników, migracje pracowników nielegalnych, migracje azylantów i osób ubiegających się o azyl polityczny, uchodźców, tj. osób spełniających wymogi konwencji ONZ z 1951 roku [Appleyard, 1991, s. 22-23]

Jednocześnie w zakresie migracji wewnętrznej w ostatnim czasie pojawił się nowy rodzaj, zwany migracją środowiskowa, ekouchodźcami lub uchodźcami środowiskowymi (ang. enviromental refugees). Pojęcie to zaproponowal już w 1976 roku, amerykański uczony, Lester Brown. Ostatecznie pojęcie to w 1985 roku zdefiniował jako pierwszy Essam El-Hinnawi, badacz Programu Środowiskowego Narodów Zjednoczo- 
nych (UNEP). El-Hinnawi określił uchodźcę ekologicznego jako osobę migrującą z powodów środowiskowych ${ }^{1}$ [Ukleja, Wójcicka].

Migracje środowiskowe mogą mieć różny wymiar czasowy (migracje sezonowe, czasowe, stałe) i przestrzenny (migracje lokalne, z obszarów wiejskich lub miejskich, z obszarów miejskich do wiejskich, międzynarodowe) co w znacznym stopniu utrudnia ocenę ich skali [Florczak].

Pierwszym, opisanym szeroko naukowo i kulturowo, przypadkiem ekomigracji były „brudne lata trzydzieste” w USA. Wówczas wyeksploatowane rolniczo-środkowe stany nawiedziła susza, a z nią suche susze pyłowe, zwane dusterami, powodując pylice i zmuszając nawet pół miliona rolników i innych mieszkańców do opuszczenia swoich gospodarstw [Dobroch, 2016, s. 94].

Międzynarodowa Organizacja do spraw Uchodźców (The State of Environmental Migration - IOM) dzieli uchodźców ekologicznych na trzy grupy:

- $\quad$ nagłych, którzy opuszczają swoje wioski i miasta w wyniku katastrof naturalnych;

- $\quad$ przymusowych, których do ucieczki zmuszają zmieniające się warunki środowiskowe i klimatyczne;

- motywowanych, którzy wybierają przeprowadzkę, by uniknąć ewentualnych problemów w przyszłości [Migration. Environmental and Climat Change..., 2009].

Tych pierwszych może przybyć na świecie już w tym roku ze względu na notowane, silne zjawisko El Nino², które przyczyniło się do największej katastrofy ekologicznej XXI wieku - pożarów w Indonezji, a w innych miejscach świata susz i powodzi. Do tych uciekinierów mogą w najbliższej przyszłości dołączyć uchodźcy klimatyczni, migrujący na skutek globalnego ocieplenia. Przewiduje się, że liczba ekouchodźców na świecie będzie drastycznie wzrastać i że przewyższy liczbę uchodźców wojennych, osiągając do 2050 roku nawet ćwierć miliona [The State of Environmental Migration..., 2013].

\section{Migracje w Polsce - czy grozi nam zjawisko ekomigracji?}

Polska należy do tych krajów, które w drugiej połowie XIX i XX wieku przeszły przez kilka faz szczególnie intensywnych migracji zewnętrznych i wewnętrznych [Encyklopedia socjologii, 1999, s. 248-249].

Jednocześnie o wielkości strumienia emigracyjnego z ziem polskich decydowały (choć nie w tym samym stopniu w różnych okresach): czynniki polityczne (utrata niepodległości i walka o jej odzyskanie, dążenia do przełamania skutków ładu jałtańsko-poczdamskiego, realizacja zmian ustrojowych w warunkach ograniczonej suwerenności, opozycja niepodległościowa, stan wojenny), niedorozwój gospodarczy i za2012].

${ }^{1}$ Więcej na temat historii pojęcia uchodźcy ekologicznego, a także zakresu tego pojęcia w: [Morrisey,

${ }^{2}$ El Nino występuje co 3-7 lat i jest zjawiskiem, które prowadzi do wzrostu temperatury wód na powierzchni równikowej wschodniego Pacyfiku, co w znaczny sposób wpływa na globalny klimat. Efektem El Nino są m.in.: susze, pożary lasów, powodzie czy problemy w rybołówstwie [Skubik, 2015]. 
cofanie cywilizacyjne, przemoc (polityka państw zaborczych, działania władz okupacyjnych), indywidualne potrzeby (ciekawość świata, aspiracje kształceniowe, kariery zawodowe itp.) i względy rodzinne (łączenie rodzin, migracje matrymonialne) [Emigracja z ziem polskich..., 1984].

Migracje wewnętrzne (w ramach terytorium II Rzeczypospolitej) nasiliły się zwłaszcza w czasie drugiej wojny światowej oraz w wyniku jej wielorakich następstw. W drugiej połowie XX wieku wraz z planowanymi procesami industralizacyjnymi zwiększyły się migracje ze wsi do miast i migracje wahadłowe. W tym czasie były one zdecydowanie większe niż migracje $\mathrm{z}$ miast do wsi, między miastami czy między wsiami [Encyklopedia socjologii, 1999, s. 248].

W Polsce najbardziej była zauważalna migracja wewnętrzna ludności ze wsi do miast, chociaż w ostatnim okresie trend ten osłabł i mniej ludności wiejskiej decyduje się na taką zmianę otoczenia. Migracja za „chlebem” do miast nie jest już dziś dobrym rozwiązaniem.

Natomiast w dzisiejszych czasach obserwuje się nowe zjawisko, które nie miało, jak dotąd, miejsca, a obecnie dotyczy nie tylko Polski, ale także państw, takich jak: Stany Zjednoczone, Japonia, a także państw Europy Zachodniej czy gwałtownie rozwijającej się Europy Środkowej [Rolecki, 2016].

Pojawienie się w ostatnim czasie nowej tendencji związanej z migracją ludności z miasta na wieś może być efektem pogarszającego się stanu środowiska naturalnego na terenie skupisk miejskich z jednej strony i rosnącej świadomości ekologicznej społeczeństwa z racji warunków środowiskowych, które maja wpływ na nasze życie $-\mathrm{z}$ drugiej strony.

W opublikowanym ostatnio raporcie Światowej Organizacji Zdrowia (WHO) przedstawiono, że większość mieszkańców miast na całym świecie jest narażonych na zanieczyszczenie powietrza przekraczające normy. Światowa Organizacja Zdrowia podczas badania brała pod uwage poziom pyłu zawieszonego PM2, $5^{3}$ i PM10 ${ }^{4}$ [Raport, 2014].

Jego czastki są tak małe, że bez problemu przenikają z płuc do krwiobiegu. Nawet krótkotrwała ekspozycja na wysokie stężenia pyłu PM2,5 powoduje wzrost liczby zgonów z powodu chorób układu oddechowego i krążenia oraz wzrost ryzyka nagłych przypadków wymagających hospitalizacji. Natomiast PM2,5 razem z pyłem PM10, silnie rakotwórczym benzo(a)pirenem oraz trującymi zwiazzkami chemicznymi (tlenkami siarki, azotu, tlenkiem węgla, metalami ciężkimi i sadza) wchodzi w skład smogu.

Raport Światowej Organizacji Zdrowia (WHO) przedstawia pomiary jakości powietrza z ponad 3 tys. miast w 103 krajach. Dane sa bardzo pesymistyczne. Powietrze

\footnotetext{
${ }^{3}$ PM2,5 - pył zawieszony zawiera cząstki o średnicy mniejszej niż 2,5 mikrometra, które mogą docierać do górnych dróg oddechowych, płuc oraz przenikać do krwi. Docelowa wartość średnioroczna dla pyłu wynosi $25 \mu \mathrm{g} / \mathrm{m}^{3}$, poziom dopuszczalny $25 \mu \mathrm{g} / \mathrm{m}^{3}$, według Wojewódzkiej Inspekcji Ochrony Środowiska (WIOŚ) w Warszawie.

4 PM10 oznacza mieszaninę substancji organicznych i nieorganicznych - w tym toksycznych, m.in.: benzo(a)pirenu, o średnicy 10 mikrometrów. Poziom dopuszczalny dla stężenia średniodobowego wynosi $50 \mu \mathrm{g} / \mathrm{m}^{3}$ i może być przekraczany nie więcej niż $35 \mathrm{dni}$ w ciagu roku. Poziom dopuszczalny dla stężenia średniorocznego wynosi $40 \mu \mathrm{g} / \mathrm{m}^{3}$, a poziom alarmowy $200 \mu \mathrm{g} / \mathrm{m}^{3}$, według WIOŚ w Warszawie.
} 
w większości miast na świecie, gdyż aż 80 proc., przekracza dopuszczalne normy. Zanieczyszczenie, mierzone liczbą pyłów zawieszonych, zwiększyło się w ciagu pięciu ostatnich lat o 8 proc. [Raport, 2014].

Niestety, w Europie niechlubnymi rekordzistami są miasta polskie. W pierwszej dziesiątce znalazło się aż siedem polskich miast, a w pierwszej pięćdziesiątce aż trzydzieści trzy. Listę najbardziej zanieczyszczonych miast w Europie otwiera Żywiec, gdzie stężenie pyłów o średnicy 2,5 mikrometra (PM2,5) przekroczyło 40 mikrogramów na metr sześcienny (zalecana przez WHO norma to nie więcej niż 25 mikrogramów na metr sześcienny $\left.-25 \mu \mathrm{g} / \mathrm{m}^{3}\right)$. Wśród większych miast Polski w czołówce znalazły się: Rybnik (4. miejsce), Wodzisław Śląski (5.), Opoczno (6.), Sucha Beskidzka (7.) i Godów (8.) oraz Kraków na 11. miejscu [http://sojp.wios.warszawa.pl/index.php?page =PM10_i_PM25, data wejścia: 03.07.2016].

\section{Kraków jako studium przypadku z powodu zanieczyszczonego powietrza}

Dotychczas opisanymi przypadkami ekomigracji w Polsce byly te odnotowane w Krakowie, dlatego metodą badań jest studium indywidualnego przypadku (case study). Jest to szczegółowa, w miarę kompletna i wyczerpująca problem badawczy, naukowa analiza jednego, szczególnego zjawiska, obiektu lub sytuacji [Olechnicki, Załęcki, 1997, s. 207; Metody badań jakoócionych, 2010, s. 624-651].

Według danych Urzędu Statystycznego, w 2015 roku w Krakowie mieszkało 761069 osób, przy czym kobiety stanowiły 53,4\%. Z danych tych wynika, że wprawdzie do roku 2008 krakowian ubywało, jednak od 2012 roku utrzymuje się dodatnie saldo migracji wewnętrznej, które w 2015 roku wyniosło 2,4\%o. Analizując strukturę wiekową mieszkańców Krakowa, należy stwierdzić, że od 8 lat notuje się dodatni przyrost naturalny, który w ostatnim roku wyniósł 0,5\%. Mimo to, w latach 2006-2013 zarejestrowano systematyczny spadek liczby ludności w wieku przedprodukcyjnym (0-17 lat), z 18\% w roku 2006 do 15,6\% w roku 2013 i niewielki wzrost w 2015 roku do $15,9 \%$. W przypadku dwóch pozostałych grup wiekowych można zaobserwować postępującą tendencję rosnąca. Wzrost liczby ludności w wieku produkcyjnym (18-59/64 lat) w badanym okresie wyniósł wprawdzie około 6 tys. mieszkańców, lecz znacząco nie wpłynęło to na udział tej grupy w całej populacji. W latach 2006-2013 oscylował on wokół poziomu $62 \%$. Niepokojąco pogłębia się proces starzenia się mieszkańców Krakowa, bowiem w latach 2006-2013 nastapił wzrost liczby ludności w wieku poprodukcyjnym $(60+/ 65+)$ z poziomu 16\% w roku 2006 do 22,1\% w roku 2015 [Rocznik Statystyczny Województwa Matopolskiego..., 2015, s.122-123, 140, 145].

Jednocześnie rejestr osób zameldowanych na pobyt stały pokazuje pewne tendencje przemieszczania się ludności Krakowa, których od 2006 roku ubyło o 11359 osób. Wielu z dotychczasowych mieszkańców wyprowadziło się do gmin podkrakowskich, gdzie m.in. powstały nowe mieszkania o bardziej konkurencyjnych cenach niż w centrum. Ubytek liczby mieszkańców Krakowa wynika na pewno z przyczyn demograficznoekonomicznych. Na ile natomiast pogarszające się warunki środowiska naturalnego również przyczyniają się do zwiększonej migracji ludności z Krakowa w inne miejsca 
obecnie nie ma jednoznacznego udokumentowania [Raport o stanie miasta..., 2016, s. 2-12]. Należy zauważyć, że pod względem statystycznym bardzo trudno jest ocenić skalę zjawiska migracji środowiskowej, a wiąże się to przede wszystkim z brakiem dostępnych technologii i badań.

Według stałego monitoringu Wojewódzkiego Inspektoratu Ochrony Środowiska w Krakowie, jakość powietrza w latach 2011-2015 określona na podstawie pomiarów na stacjach monitoringu w Krakowie wskazuje, iż corocznie były rejestrowane przekroczenia norm co do stężeń: pyłu PM10, PM2,5 oraz benzo(a)pirenu. Tabela 1. przedstawia wartości stężeń zanieczyszczeń, które zostały przekroczone w Krakowie.

TABELA 1.

Wartości stężeń średniorocznych pyłu PM10, PM2,5 i benzo(a)pirenu na stacjach monitoringu jakości powietrza w Krakowie, w latach 2011-2015

\begin{tabular}{|c|c|c|c|c|c|}
\hline \multirow{2}{*}{$\begin{array}{l}\text { Lokalizacja stacji } \\
\text { pomiarowej } \\
\text { (stacje mobilne) }\end{array}$} & \multicolumn{5}{|c|}{$\begin{array}{c}\text { Stężenie średnioroczne pyłu PM10 [ }\left[\mu \mathrm{g} / \mathrm{m}^{3}\right] \\
\text { Poziom dopuszczalny (od } 2005 \mathrm{roku}): 40 \mu \mathrm{g} / \mathrm{m}^{3}\end{array}$} \\
\hline & 2011 & 2012 & 2013 & 2014 & 2015 \\
\hline Kraków, ul. Bujaka & 54 & 53 & 44 & 46 & 45 \\
\hline Kraków, Al. Krasińskiego & 77 & 66 & 60 & 64 & 68 \\
\hline Kraków, ul. Bulwarowa & 63 & 51 & 49 & 49 & 52 \\
\hline \multirow{2}{*}{$\begin{array}{l}\text { Lokalizacja stacji } \\
\text { pomiarowej } \\
\text { (stacje mobilne) }\end{array}$} & \multicolumn{5}{|c|}{$\begin{array}{c}\text { Stężenie średnioroczne pyłu PM25 }\left[\mu \mathrm{g} / \mathrm{m}^{3}\right] \\
\text { Poziom dopuszczalny (od } 2015 \mathrm{roku}): 25 \mu \mathrm{g} / \mathrm{m}^{3} \text {, } \\
\text { (od } 2020 \text { roku): } 20 \mu \mathrm{g} / \mathrm{m}^{3}\end{array}$} \\
\hline & 2011 & 2012 & 2013 & 2014 & 2015 \\
\hline Kraków, ul. Bujaka & 37 & 41 & 33 & 33 & 34 \\
\hline Kraków, Al. Krasińskiego & 42 & 38 & 35 & 32 & 33 \\
\hline Kraków, ul. Bulwarowa & 55 & 47 & 44 & 45 & 44 \\
\hline $\begin{array}{l}\text { Lokalizacja stacji } \\
\text { pomiarowej }\end{array}$ & \multicolumn{5}{|c|}{$\begin{array}{l}\text { Stężenie średnioroczne benzo(a)pirenu }\left[\mathrm{ng} / \mathrm{m}^{3}\right] \\
\text { Poziom docelowy (do } 2013 \text { roku): } 1 \mathrm{ng} / \mathrm{m}^{3}\end{array}$} \\
\hline (stacje mobilne) & 2011 & 2012 & 2013 & 2014 & 2015 \\
\hline Kraków, ul. Bujaka & 9 & 6 & 5 & 8 & 8 \\
\hline Kraków, ul. Bulwarowa & 10 & 8 & 8 & 7 & 7 \\
\hline
\end{tabular}

Źródło: opracowanie własne na podstawie danych WIOŚ w Krakowie: [Program Ochrony Powietrza..., 2016a, s. 5-10].

Analiza wielkości emisji wymienionych zanieczyszczeń w Krakowie wykazuje, iż największe stężenia zanotowano co do benzo(a)pirenu, w przypadku którego stężenie przekracza dopuszczalne normy ponad 7-8-krotnie. Problem zanieczyszczenia powietrza benzo(a)pirenem jest problemem ogólnopolskim ale mieszkańcy południowej części kraju (w tym Krakowa) są szczególnie narażeni na wysokie stężenia tego rakotwórczego zanieczyszczenia.

Natomiast w przypadku pyłu PM10 odnotowano najwięcej dni ze średniodobowym przekroczeniem norm powyżej $50 \mu \mathrm{g} / \mathrm{m}^{3}$, w sytuacji gdy stężenia średnioroczne pyłu 
PM10 moga przekraczać podaną wartość jedynie przez 35 dni w roku. Tabela 2. przedstawia ilość dni, w których nastąpiło przekroczenie dopuszczalnego stężenia w przypadku pyłu PM10.

TABELA 2.

Ilość dni z przekroczeniami dopuszczalnych stężeń 24-godzinnych pyłu PM10 na stacjach pomiarowych w Krakowie, w latach 2011-2015

\begin{tabular}{|l|c|c|c|c|c|}
\hline \multirow{2}{*}{$\begin{array}{c}\text { Lokalizacja stacji } \\
\text { pomiarowej }\end{array}$} & \multicolumn{5}{c|}{$\begin{array}{c}\text { Liczba dni z wystąpieniem stężeń 24-godzinnych } \\
\text { pyłu PM10 powyżej 50 } \mathbf{\mu g} / \mathbf{m}^{\mathbf{3}}\end{array}$} \\
& \multicolumn{4}{|c|}{ Dopuszczalna liczba dni (od 2005 roku): 35 } \\
\cline { 2 - 6 } & $\mathbf{2 0 1 1}$ & $\mathbf{2 0 1 2}$ & $\mathbf{2 0 1 3}$ & $\mathbf{2 0 1 4}$ & $\mathbf{2 0 1 5}$ \\
\hline Kraków, ul. Bujaka & 127 & 116 & 106 & 100 & 99 \\
Kraków, Al. Krasińskiego & 174 & 122 & 136 & 123 & 120 \\
Kraków ul. Bulwarowa & 200 & 132 & 158 & 188 & 200 \\
\hline
\end{tabular}

Źródło: opracowanie własne na podstawie danych WIOŚ w Krakowie: [http://monitoring. krakow.pios.gov.pl/, data wejścia: 14.12.2016].

Mieszkańcy Krakowa od wielu lat oddychają bardzo zanieczyszczonym powietrzem. Wynika to z uwarunkowań związanych z określonym położeniem geograficznym oraz panującymi warunkami klimatycznymi i geologicznymi. Kraków jest zlokalizowany w większej części w zagłębieniu terenu (niejako niecce), co często uniemożliwia przewietrzanie przestrzeni ponad miastem i dodatkowo sprzyja inwersjom temperatury. Właśnie to jest powodem, że od listopada do marca można tutaj bardzo często zaobserwować gęsty smog, a pomiary niejednokrotnie wykazują kilkukrotne przekroczenia norm stężenia pyłu zawieszonego. Dlatego problem zanieczyszczenia powietrza, z jakim mamy do czynienia w Krakowie, dotyka tylko wybranych miast czy metropolii, nie sprawiając większych kłopotów $\mathrm{w}$ innych o podobnych ilościach produkowanych zanieczyszczeń (np.: ze spalin samochodowych czy z lokalnych źródeł ciepła itp.). Dodatkowo nasilenie tego zjawiska jest uzależnione od pory roku i panujących warunków atmosferycznych.

Powierzchnię obszaru narażonego na ponadnormatywne stężenie zanieczyszczeń wraz z liczbą ludności narażonej na zanieczyszczenia prezentuje tabela 3.

Biorąc pod uwagę dobowe stężenie pyłu PM10 na terenie województwa, na przekroczenie wartości dopuszczalnej $50 \mathrm{~g} / \mathrm{m}^{3}$ przez więcej niż 35 dni jest narażonych ponad 50\% mieszkańców Małopolski (1 686,5 tys.) na obszarze około 1,2 tys. km² (8,2\% powierzchni województwa). Najwyższe stężenie, przekraczające dopuszczalny poziom, wyznaczono na obszarze: Krakowa, Nowego Sącza, Nowego Targu i Chrzanowa [Program ochrony powietrza..., 2016b, s. 12-13]. 
TABELA 3.

Obszar narażenia i liczba narażonych mieszkańców na ponadnormatywne, średnioroczne stężenia pyłu PM10, PM2,5 w Aglomeracji Krakowskiej, w 2015 roku

\begin{tabular}{|c|c|c|}
\hline Strefa ochrony powietrza & $\begin{array}{c}\text { Powierzchnia obszaru } \\
\text { narażenia } \\
\left.(\mathbf{w ~ k m})^{2}\right)\end{array}$ & $\begin{array}{l}\text { Liczba narażonych } \\
\text { mieszkańców }\end{array}$ \\
\hline & \multicolumn{2}{|c|}{ Pyłu PM10 } \\
\hline Aglomeracja Krakowska & 42,31 & 285653 \\
\hline \multirow[t]{2}{*}{ Województwo małopolskie } & 60,84 & 352287 \\
\hline & \multicolumn{2}{|c|}{ Pyłu PM2,5 } \\
\hline Aglomeracja Krakowska & 155,01 & 695362 \\
\hline Województwo małopolskie & 295,23 & 1072604 \\
\hline \multirow{2}{*}{\multicolumn{3}{|c|}{$\begin{array}{l}\text { Narażenie na ponadnormatywne stężenie 24-godzinne pyłu PM10 powyże } \\
\qquad 35 \mathrm{dni} \text { w roku i pyłu PM2,5 }\end{array}$}} \\
\hline & & \\
\hline & \multicolumn{2}{|c|}{ Pyłu PM10 } \\
\hline \multirow{3}{*}{$\begin{array}{l}\text { Aglomeracja Krakowska } \\
\text { Województwo } \\
\text { małopolskie }\end{array}$} & 321,89 & 761069 \\
\hline & 1252,70 & 1686545 \\
\hline & \multicolumn{2}{|c|}{ Pyłu PM2,5 } \\
\hline Aglomeracja Krakowska & 155,01 & 695362 \\
\hline $\begin{array}{l}\text { Województwo } \\
\text { małopolskie }\end{array}$ & 295,23 & 1072604 \\
\hline
\end{tabular}

Źródło: opracowanie własne na podstawie danych WIOŚ w Krakowie: [http://monitoring. krakow.pios.gov.pl/, data wejścia: 15.12.2016].

Uciążliwość zanieczyszczenia powietrza atmosferycznego w Krakowie potwierdziły także dane z tzw. Barometru Krakowskiego. Jest to cykliczne badanie opinii i preferencji mieszkańców Krakowa, które jest źródłem wiedzy dla władz miasta na temat społecznego odbioru różnorodnych problemów Krakowa oraz oceny działań władz miasta przez mieszkańców.

Badanie zostało przeprowadzone za pomoca metody wywiadu kwestionariuszowego (bezpośredniego) wśród wylosowanej grupy 1125 mieszkańców Krakowa i wśród 300 studentów mieszkających w krakowskich akademikach. Ankieterzy odwiedzili wylosowane adresy i przeprowadzili wywiad z mieszkańcami z wykorzystaniem kwestionariusza wywiadu. Losowanie mieszkańców zostało oparte na bazie adresowej, a wybór respondentów był niezależny od tego, czy osoba badana była zameldowana w Krakowie. Badanie przeprowadzono w dwóch turach: w turze letniej, w której przeprowadzono 307 wywiadów z mieszkańcami i 300 wywiadów ze studentami krakowskich akademików (w dniach 8 czerwca-29 lipca 2015 roku) i turze zimowej, w której przeprowadzono 818 wywiadów z mieszkańcami (w dniach 7 września-29 października) [Chrza- 
nowski, 2015, s. 11]. Badanie potwierdziło, że czystość powietrza negatywnie oceniło aż 61\% respondentów, a poziom hałasu w mieście był uciążliwy dla $40 \%$ mieszkańców Krakowa biorących udział w badaniu.

Ponadnormatywne stężenia zanieczyszczeń powietrza atmosferycznego, jakie mają miejsce w Krakowie, są przyczyną zwiększonego poziomu zachorowalności na choroby układu oddechowego i nowotwory. W Krakowie zanotowano średnio 394 przypadki zachorowań na nowotwór płuca rocznie [Raporty KRN].

Z tego, jak oszacowała organizacja HEAL Polska ${ }^{5}, 25 \%$ tych przypadków w Krakowie było wywoływanych zanieczyszczeniem powietrza [Rakotworcze powietrze..., 2016]. Badania wykazywały, że zanieczyszczone powietrze było powodem średnio 1,4\% z całkowitej liczby zgonów, 0,5\% z przypadków całkowitego inwalidztwa, 2\% chorób serca [Sedlak, 2014, s. 16-21]

W 2013 roku Komisja Europejska podała, że w roku 2010 koszty zwiazane z wpływem zanieczyszczeń na zdrowie wahały się w całej Unii Europejskiej między 330-920 mld euro.

Skutkami narażenia na zanieczyszczenie powietrza są:

- zwiększona śmiertelność;

- $\quad$ wizyty szpitalne z powodu chorób układu krązenia i układu oddechowego;

- interwencje pogotowia ratunkowego w wyniku ataków chorób układu oddechowego lub krążenia;

- nieobecność w pracy czy w szkole;

- $\quad$ ostre symptomy (kaszel, infekcje dróg oddechowych);

- $\quad$ koszty leczenia chorób układu oddechowego i krwionośnego.

W skali kraju koszty zewnętrzne wszystkich chorób i zgonów, będących następstwem naruszenia norm jakości powietrza, oszacowano na 8 mld złotych. Połowa to pieniądze przeznaczone na leczenie chorób płuc (astma) i nowotworów. Druga połowa ma pomóc osobom cierpiącym na choroby układu krążenia, które również znalazły się na liście schorzeń wywołanych przez zanieczyszczenia w powietrzu, takie jak pyły i benzo(a)piren [Program ochrony powietrza..., 2016a, s. 26-27].

\section{Podsumowanie}

Wpływ środowiska na życie i zdrowie człowieka nabiera coraz większego znaczenia. Świadczy o tym fakt, że prawo człowieka do życia w czystym środowisku stanowi podstawową zasadę zrównoważonego rozwoju ${ }^{6}$. Została ona sformułowana w prawie mię-

\footnotetext{
${ }^{5}$ Health and Environment Alliance (HEAL) to międzynarodowa organizacja, która analizuje wpływ środowiska na zdrowie obywateli Unii Europejskiej, z siedzibą w Brukseli (www.env-health.org). Od 2013 roku funkcjonuje biuro lokalne w Warszawie (www.healpolska.pl). Dzięki monitorowaniu stężeń zanieczyszczeń powietrza, śledzeniu rozwiązań technologicznych oraz udziale w tworzeniu regulacji prawnych dąży ona do poprawy jakości powietrza na terenie całej Polski, a szczególnie w jej najbardziej zanieczyszczonych regionach.

6 Została ona podjęta na „Szczycie Ziemi w Rio de Janerio” w 1992 roku i uwzględniona w Deklaracji w sprawie środowiska i rozwoju.
} 
dzynarodowym i wdrożona w Konstytucji Rzeczypospolitej Polskiej w art. 5, który stanowi: (...) Rzeczpospolita Polska (...) rapewnia ochrone środowiska, kierujac sie zasada zrónnoważonego rozwoju (...) [Konstytucja $\mathrm{RP}, 1997]$.

Pojawienie się w ostatnim czasie nowej tendencji dotyczącej migracji ludności z miasta na wieś może być efektem pogarszającego się stanu środowiska naturalnego na terenie skupisk miejskich z jednej strony i rosnącej świadomości ekologicznej społeczeństwa pod względem warunków środowiskowych, które mają wpływ na nasze życie $z$ drugiej strony.

Jednak nadal przyczyny ekomigracji z miasta na wieś nie są dokładnie zbadane, by można było jednoznacznie dowieść o ich oddziaływaniu na ruchy migracyjne krakowian.

Mimo to, w dobie wzrastającej świadomości ekologicznej społeczeństwa związanej z wpływem pogarszających się warunków życia na zdrowie i jakość życia można liczyć się z nasileniem tego zjawiska.

\section{Literatura}

Appleyard R. T., 1991, International Migration: Challenge for the Ninenties, IOM, Geneve. Chrzanowski M., 2015, Barometr Krakowski. Raport Badawrzyy, Urząd Miasta Krakowa, Karków.

Dobosiewicz Z., Olszewski T., 1982, Geografia ekonomiczna śniata, Państwowe Wydawnictwo Ekonomiczne, Warszawa.

Dobroch B., 2016, Smogowi uchodźcy, „Polityka”, nr 3(3042), 13.01.-19.01.2016.

Emigracja z. ziem polskich w crasach nowosiytnych i najnowssych, 1984, A. Pilch (red.), Państwowe Wydawnictwo Naukowe, Warszawa.

Encyklopedia socjologii, 1999, Wydawnictwo Naukowe PWN, Warszawa.

Florczak A., 2014, Uchodźstwo, www.repozytorium.uni.wroc.pl/Content/6929/18_ Agnieszka_Florczak.pdf (data wejścia: 16.12.2016).

Holzer J. Z., 1994, Demografia, Państwowe Wydawnictwo Ekonomiczne, Warszawa. http://monitoring.krakow.pios.gov.pl/ (data wejścia: 15.12.2016).

http://sojp.wios.warszawa.pl/index.php?page=PM10_i_PM25 (data wejścia: 03.07.2016).

Konstytucja RP z. dnia 2 kwietnia 1997 roku, Dz. U. 1997, Nr 78, poz. 483.

Latuch M., 1985, Demografia społeczno-ekonomiczna, Państwowe Wydawnictwo Ekonomiczne, Warszawa.

Maryański A., 1984, Migracje w śmiecie, Państwowe Wydawnictwo Naukowe, Warszawa.

Metody Badań Jakościonych, 2010, N. K. Denzin, Y.S. Lincoln (red.), t. 1, Wydawnictwo Naukowe PWN, Warszawa.

Migration. Environmental and Climat Change: Assesing the Evidence, 2009, F. Laczko, Ch. Aghazarm (eds.), International Organization for Migration, Geneva.

Morrisey J., 2012, Rethinking the 'debate on environmental refugees': from 'maximilists and minimalists' to 'proponents and critics', "Journal of Political Ecology", vol. 19. 
Olechnicki K., Załęcki P., 1997, Stownik socjologicænyy, „Grafitti BC”, Toruń.

Ottolenghi C., 1994, International Organization for Migration (IOM) and its Role vis-a-vis Migrant Workers, Raport IOM przedstawiony na seminarium KBWE w Warszawie, 21-25 marca 1994 roku.

Program ochrony powietrza dla województwa matopolskiego. Matopolska w zdrowej atmosferze, 2016a, Urząd Marszałkowski Województwa Małopolskiego, Kraków.

Program ochrony powietrza dla województwa matopolskiego. Matopolska w zdrowej atmosferze, 2016b, Uzasadnienie, Urząd Marszałkowski Województwa Małopolskiego, Kraków.

Rakotwórcze powietrze - kalkulacje HEAL dot. wplywu zaniecsyszczeń powietrza na zapadalność na nowotwór pluca, 2016, http://healpolska.pl/aktualnosci/rakotworcze-powietrzekalkulacje-heal-dot-wpływu-zanieczyszczen-powietrza-na-zapadalnosc-na-nowotwórpluca/ (data wejścia: 14.12.2016).

Raport o stanie miasta. O Krakowie $i$ krakowianach 2015, 2016, Urząd Marszałkowski Województwa Małopolskiego, Kraków.

Raport, 2014, WHO, http://www.who.int/phe/health_topics/outdoorair/databases /cities/en/ (data wejścia: 14.12.2016).

Raporty KRN, http://onkologia.org.pl/raporty/ (data wejścia: 15.12.2016).

Rocznik Statystyczny Województwa Matopolskiego. Podregiony. Gminy. Powiaty, 2015, Urząd Statystyczny w Krakowie, Kraków.

Rolecki M., 2016, WHO: Ponad 80 proc. ludzi w miastach oddycha zaniecryszcronym powietrzem, http://wyborcza.pl/1,134154,20074237,who-ponad-80-proc-ludzi-wmiastach-oddycha-zanieczyszczonym.html?disableRedirects=true. $\quad($ data wejścia: 03.07.2016).

Rosset E., 1975, Demografia Polski, Państwowe Wydawnictwo Naukowe, Warszawa.

Salt J., 1989, A Comparative Overview of International Trends and Types, "International Migration Review", t. 23.

Skubik M., 2015, Nadchodri El Nino, a wraz. z. nim ekstremalna pogoda, http://wyborcza.pl/ 1,75400,17952514,Nadchodzi_El_Nino_a_wraz_z_nim_ekstremalna_pogoda. html (data wejścia: 04.07.2016).

The State of Environmental Migration 2013, International Organization for Migration, https://poland.iom.int/ publications-and-multimedia (data wejścia: 16.12.2016).

Ukleja A., Wójcicka M., Ochrona prawa do sycia w caystym środowisku naturahym i migracje ekologične, https://www.researchgate.net/profile/Aleksandra_Ukleja2/publication/26 1548559_Ochrona_prawa_do_zycia_w_czystym (data wejścia: 16.12.2016).

Widgren J., 1990, International Migration and Regional Stability, "International Affairs", no. 4.

Zolberg A. R., 1989, The Next Waves: Migration Theory for a Changing World, "International Migration Review", no. 3. 